\title{
The Effect of Locus of Control, Need for Achievement, Risk Tolerance, and Entrepreneurial Alertness on the Entrepreneurial Intention
}

\author{
Oey Hannes Widjaya ${ }^{1 *}$ Herlina Budiono $^{1}$ Hendra Wiyanto $^{1}$ Fransisca Fortunata ${ }^{1}$ \\ ${ }^{1}$ Faculty of Economics and Business, Universitas Tarumanagara, Jakarta, Indonesia \\ "Corresponding author. Email: hannesw@fe.untar.ac.id
}

\begin{abstract}
Economic problems require resolution for various unemployment, weak industrial competitiveness in global markets, job creation, income distribution, and poverty eradication, and technological change. Growing interest in entrepreneuship is expected to create new jobs to reduce unemployment. The government is trying to promote entrepreneurial activities for young entrepreneurs including students, so in this research the respondents came from Law Faculty students to find out how much effort they had in having an interest in entrepreneurship. The aims of study is to decide the effect of locus of control, need for achievement, risk tolerance, and entrepreneurial alertness on entrepreneurial intention. The sample consisted of 100 Law Faculty students as respondent, used a purposive sampling technique. Multiple regression was perfume using the random effect method of IBM SPSS software version 23. The results showed that there was a significant effect between risk tolerance and entrepreneurial alertness towards entrepreneurial intention, while the locus of control and need for achievement did not have a significant effect on the entrepreneurial intention.
\end{abstract}

Keywords: Locus of Control, Need for Achievement, Risk Tolerance, Entrepreneurial Alertness, Entrepreneurial Intention

\section{INTRODUCTION}

\subsection{Background}

The economy that hit Indonesia with various economic problems created Indonesia is a task that must be completed by the government with various solutions. According to Chester A. Barnard in [1], reveals that the Indonesian economy is a system that is basically is a large organization and with the ability to apply reason to experience professionals in developing organizational science. The Indonesian economy has several faces problems, such as: unemployment, weak industrial competitiveness in global markets, creation employment, income distribution, poverty eradication and technological change [2].

The government tries to promote entrepreneurial activities in Indonesia with helping entrepreneurs and actors from the business world to provide spirit of entrepreneurship and support both in terms of capital, mentoring and something regulations [3]. The government introduced this world of entrepreneurship to young business actors such as students from SD, SMP, SMA and students from various colleges or universities with an approach through competitions to be aware against entrepreneurial activity, it takes refuge in research that uses respondents from students of the Faculty of Law, Universitas Tarumanagara to know any big business the student has an interest in entrepreneurship. Looking at the existing problems, it can be seen that it takes an effort to address these solutions. By increasing the entrepreneurial spirit of students, especially in students then can foster interest in entrepreneurship so that the field is available new jobs to reduce existing unemployment. [4] believe that interest Entrepreneurship is a plan in building and pursuing a career in business ownership. Interest entrepreneurship can be influenced by several behaviors or personality traits among others are locus of control, need for achievement, risk tolerance and entrepreneurial alertness that is a behavior or action that can affect a person's interest in entrepreneurship.

Based on the background that has been presented, the researcher summarizes the formulation The problem becomes four, namely whether the locus of control has an influence on interest entrepreneurship, does need for achievement have an influence on interest in entrepreneurship, whether risk tolerance can influence entrepreneurial interest, and whether entrepreneurial Alertness can affect interest in entrepreneurship. 


\subsection{Theoretical Review}

The Theory of Planned Behavior (TPB), which was put forward by [5], because of research This is done with the availability of existing data, so this research is based on the TPB theory which focuses on several variables categorized as determining the level of interest in entrepreneurship. Based on the TPB theory, intention or interest is a direct antecedent of behavior and itself is a function of attitudes toward behavior, subjective norms, and control perceived behavior, and these determinants follow each of the beliefs about possible behavior, about the normative expectations of important others, and about the existence of factors that control behavioral performance.

Locus of Control. The definition of locus of control according to [6] is: "where some individuals have a firm belief in controlling their destiny temporarily others believe in the power of luck in influencing life events they". Meanwhile, according to [7], locus of control is: "variable personality related to a person's general expectation of whether a person will be controlling events in life or not.

Need for Achievement. According to [8], that can be defined as competitive behavior, characterized by a standard of excellence. Then, along over time, According to [9], need for achievement refers to desire individual for significant achievement. It also refers to a tendency to choose and stick to activities that have a moderate or their chance of success which provides the maximum opportunity for personal fulfillment satisfaction.

Risk Tolerance. The definition of risk tolerance according to [10] is: as willingness individuals to engage in behavior where there is a desired goal but an achievement objectives are uncertain and accompanied by possible losses. According to [11], risk tolerance is: the level of a person's willingness to pursue an uncertain action, Offering a relatively large gift, for sure, offers a gift that is relatively small.

Entrepreneurial Alertness. According to [12], entrepreneurial alertness is: point to awareness, evaluation and direction towards environmental ambiguity and change, that is means building an internal individual, with associated entrepreneurial alertness combine certain characteristics should spot new opportunities. Meanwhile, according to [9], entrepreneurial alertness is referring to the ability to pay attention without the search for opportunities that had hitherto been ignored. Entrepreneurial interest.

Understanding according to [13], Interest in entrepreneurship is the determination of an individual who can start a new business. [14], stated that entrepreneurial interest is a cognitive representation of action which must be carried out by individuals to build new independent businesses or creating new value in existing companies. The framework in this study can be described as follows:

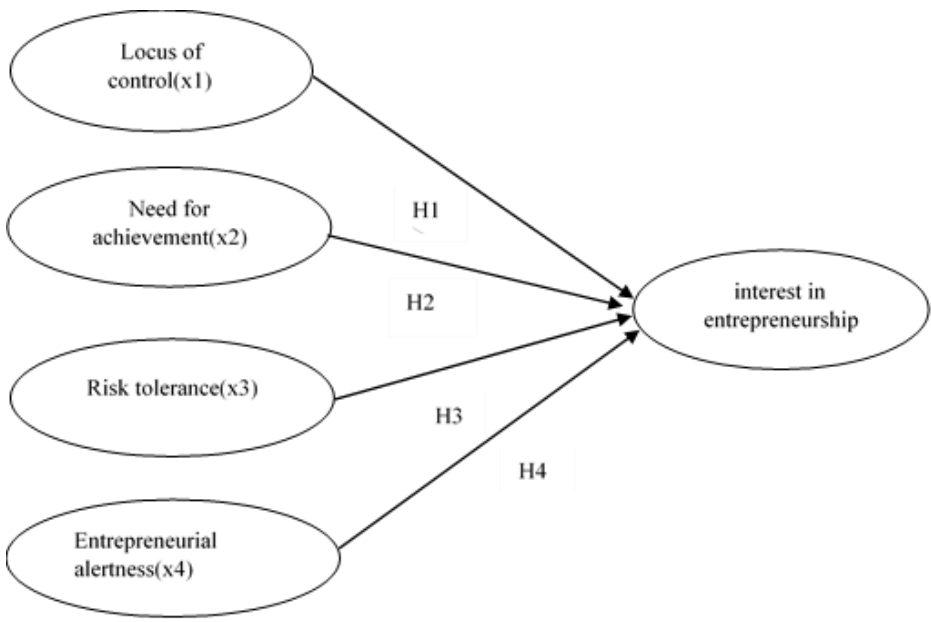

Figure 1. Framework

The hypotheses that can be constructed are as follows:

$\mathrm{H}_{1}$ : Locus of Control has a positive influence on interest in entrepreneurship.

$\mathrm{H}_{2}$ : Need for Achievement, there is a positive influence on interest in entrepreneurship

$\mathrm{H}_{3}$ : There is a negative influence on Risk Tolerance on interest in entrepreneurship

$\mathrm{H}_{4}$ : Entrepreneurial Alertness has a positive influence on interest in entrepreneurship

\section{RESEARCH METHOD}

The population chosen were students from the Faculty of Law, Universitas Tarumanagara. The sample selection is done by means of convenience sampling, which means that the sample selection is taken based on the convenience of the researcher regarding to find respondent who could provide information build upon knowledge or experience ([15]; [16]). The number of respondents in the Faculty of Law, Universitas Tarumanagara as many as 100 students who can be said to be the subjects of this study.

The objects in this study consist of locus of control, need for achievement, risk tolerance, and entrepreneurial alertness which are independent variables and interest in entrepreneurship which is the dependent variable. Variable operationalization can be seen in the following table. 
Table 1. Variable Operationalization

\begin{tabular}{|c|c|c|c|}
\hline Variable & Statement & Scale & Source \\
\hline \multirow{3}{*}{$\begin{array}{l}\text { Locus of Control } \\
\qquad\left(X_{1}\right)\end{array}$} & Persistence and hard work generally leads to success & \multirow{3}{*}{ Interval } & \multirow{3}{*}[17]{} \\
\hline & If I don't succeed at an assignment, I lean to give up & & \\
\hline & I don't such believe in luck & & \\
\hline \multirow{10}{*}{$\begin{array}{c}\text { Need for } \\
\text { Achievement }\left(X_{2}\right)\end{array}$} & I want and chasing success & \multirow{10}{*}{ Interval } & \multirow{10}{*}[17]{} \\
\hline & $\begin{array}{l}\text { I will look for additional commitment in the work assigned to } \\
\text { me }\end{array}$ & & \\
\hline & Try harder to verify my previous job evaluation & & \\
\hline & Enjoy completed the assignments & & \\
\hline & $\begin{array}{l}\text { I link failure nor success for me rather than other people or } \\
\text { circumstances }\end{array}$ & & \\
\hline & Will to perform better than others & & \\
\hline & Will do perfectly in quite tough tasks related studies or job & & \\
\hline & I restore unfinished assignments and finish it & & \\
\hline & Try hard sometimes to study new thing & & \\
\hline & I have worry of failure & & \\
\hline \multirow{2}{*}{ Risk Tolerance $\left(X_{3}\right)$} & I may not start a business if there is a risk of possible failure & \multirow{2}{*}{ Interval } & \multirow[t]{2}{*}[17]{} \\
\hline & I see the risk of failure is a major problem & & \\
\hline \multirow{4}{*}{$\begin{array}{c}\text { Entrepreneurial } \\
\text { Alertness }\left(X_{4}\right)\end{array}$} & Thinking of new business ideas while traveling & \multirow{4}{*}{ Interval } & \multirow{4}{*}[17]{} \\
\hline & Percentage of peak hours aimed at increasing business & & \\
\hline & Thinking of a new business idea & & \\
\hline & Trade publications are read annually & & \\
\hline \multirow{6}{*}{$\begin{array}{c}\text { Interest in } \\
\text { Entrepreneurship } \\
\text { (Y) }\end{array}$} & Prepared to make whatever to become an entrepreneur & \multirow{6}{*}{ Interval } & \multirow{6}{*}[18]{} \\
\hline & Set professional purpose as an entrepreneur & & \\
\hline & I will try with all my effort to start and run my business & & \\
\hline & Decided to create the company of the future & & \\
\hline & I have very serious thoughts in starting a company & & \\
\hline & I have strong intentions to start a company one day & & \\
\hline
\end{tabular}

According to [19], "In general, the research method is defined as a scientific way to obtain data with specific purposes and uses". Type of research used in this research is descriptive research and the data that has been obtained can be used to understand, solve and anticipate problems. The technique used in this research is non-probability purposive sampling technique.

This study uses validity and reliability tests. The data analysis used multiple regression analysis, F hypothesis test, t-test and determination coefficient test. The classical assumption test consists of a normality test using a probability plot (p-p plot) and also a non-parametic Kolmogorov-Smirnov. In addition there is also a multicollinearity test and heteroscedasticity test using Scatterplots.

In the validity test, all instruments used are valid based on each factor indicator using the corrected item-total correlation $\geq 0.2$ [20], then the measurement is declared valid. Whereas in the reliability test, measuring reliability 
with the Cronbach Alpha statistical test, where if the cronbach alpha coefficient value $>0.6$, it is reliable [21]. Multicollinarity [22]. Posit the multicollinearity test results, the tolerance value of each variable is more than 0.100 (>
$0.1)$ and the VIF value in each variable is below $10.00(<$ $10)$.

Table 2. Multicollinearity Test Results

\begin{tabular}{|l|l|c|c|l|}
\hline No & \multicolumn{1}{|c|}{ Variable } & Tolerance & VIF & \multicolumn{1}{|c|}{ Result } \\
\hline 1 & Locus of Control & 0.776 & 1.289 & $\begin{array}{l}\text { There is no } \\
\text { multicollinearity }\end{array}$ \\
\hline 2 & Need for Achievement & 0.846 & 1.181 & $\begin{array}{l}\text { There is no } \\
\text { multicollinearity }\end{array}$ \\
\hline 3 & Risk Tolerance & 0.855 & 1.169 & $\begin{array}{l}\text { There is no } \\
\text { multicollinearity }\end{array}$ \\
\hline 4 & Entrepreneurial Alertness & 0.783 & 1.278 & $\begin{array}{l}\text { There is no } \\
\text { multicollinearity }\end{array}$ \\
\hline
\end{tabular}

Source: SPSS Output

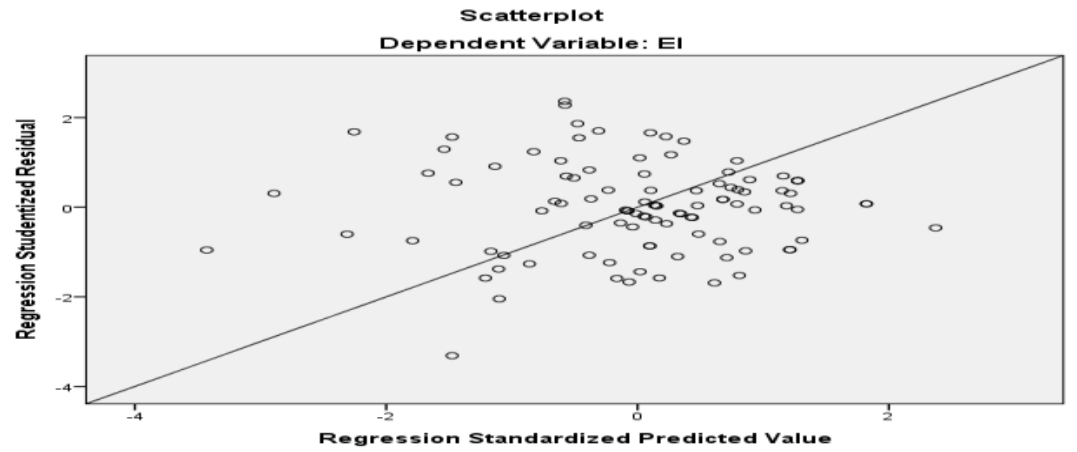

Figure 2. Heteroscedasticity test results for the Scatterplot chart. Source: Output SPSS

In the Scatter Plot graph, the image pattern is shapeless and the dots spread amongst $\mathrm{Y}$ axis, so in this study there is no heteroscedasticity [22].

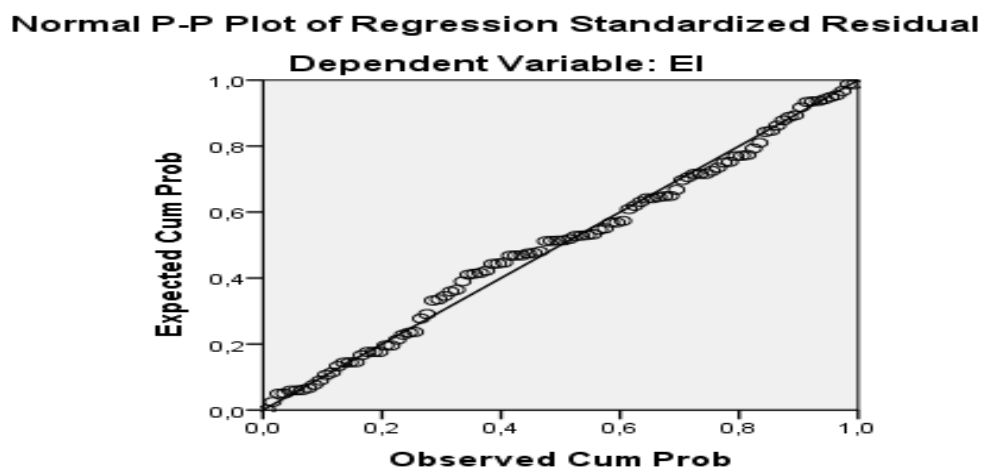

Figure 3. The test results of the normal probability plot (P-Plot) graph. Source: SPSS output

Whereas in the normality test, Figure 3 shows that the normal distribution with a straight diagonal line means the distribution of residual data is normal, the line describing the actual data will follow the diagonal line [22].

\section{RESULTS AND DISCUSSION}

\subsection{Data Analysis Results}

The test on multiple regression analysis in table 3 shows that the equation formed is: $\mathrm{Y}=1.463+0.018 \mathrm{X}_{1}+0.204 \mathrm{X}_{2}$ $0.133 \mathrm{X}_{3}+0.557 \mathrm{X}_{4}$ 
Table 3. Multiple Regression Analysis Table

Coefficients $^{a}$

\begin{tabular}{|c|c|c|c|c|c|c|}
\hline \multirow{2}{*}{\multicolumn{2}{|c|}{ Model }} & \multicolumn{2}{|c|}{ Unstandardized Coefficients } & \multirow{2}{*}{$\begin{array}{c}\text { Standardized } \\
\text { Coefficients } \\
\text { Beta }\end{array}$} & \multirow[b]{2}{*}{$\mathrm{t}$} & \multirow[b]{2}{*}{ Sig. } \\
\hline & & $\mathrm{B}$ & Std. Error & & & \\
\hline \multirow[t]{5}{*}{1} & (Constant) & 1,463 & .492 & & 2,972 & .004 \\
\hline & $N$ &, 204 &, 119 & .141 & 1,723 & ,088 \\
\hline & LC & ,018 &, 059 &, 026 &, 304 &, 762 \\
\hline & EA &, 557 &, 078 & .608 & 7,140 &, 000 \\
\hline & RT &,- 133 & .054 & -199 & $-2,441$ & .017 \\
\hline
\end{tabular}

a. Dependent Variable: El

Source: SPSS Output

Based on the SPSS output in table 3, the results of the hypothesis test are formed as in table 4 below:

Table 4. Hypothesis Test Results

\begin{tabular}{|l|l|c|}
\hline \multicolumn{1}{|c|}{ Hypothesis } & Result \\
\hline 1 & $\begin{array}{l}\text { Locus of Control has a positive relationship with students' interest in entrepreneurship } \\
\text { in the Faculty of Law, Universitas Tarumanagara, but not significant }\end{array}$ & Rejected \\
\hline 2 & $\begin{array}{l}\text { Need for Achievement has a positive relationship with students' interest in } \\
\text { entrepreneurship at the Faculty of Law, Universitas Tarumanagara, but not significant }\end{array}$ & Rejected \\
\hline 3 & $\begin{array}{l}\text { Risk Tolerance has a negative relationship with students' interest in entrepreneurship } \\
\text { in the Faculty of Law, Universitas Tarumanagara, but significant }\end{array}$ & Accepted \\
\hline 4 & $\begin{array}{l}\text { Entrepreneurial Alertness has a positive and significant relationship with students' } \\
\text { interest in entrepreneurship in Law Faculty, Universitas Tarumanagara }\end{array}$ & Accepted \\
\hline
\end{tabular}

The significance of the results of the $\mathrm{F}$ hypothesis test is 0.000 in table 5 below, where the value is less than 0.05 , which can be concluded that there is a significant influence between the independent variables (locus of control, need for achievement, risk tolerance, and entrepreneurial alertness) the dependent variable (interest in entrepreneurship).

Table 5. F-Test Results

\begin{tabular}{|ll|r|r|r|r|c|}
\hline Model & & $\begin{array}{c}\text { Sum of } \\
\text { Squares }\end{array}$ & df & Mean Square & F & Sig. \\
\hline 1 & Regression & 23,117 & 4 & 5,779 & 20,334 &, $000^{\mathrm{b}}$ \\
& Residual & 27,001 & 95 &, 284 & & \\
& Total & 50,118 & 99 & & & \\
\hline
\end{tabular}

Source: SPSS Output

Based on table 6 below, the value of Adjusted R Square is 0.439 or $43.9 \%$ where the independent variable has an influence on the dependent variable, while $56.1 \%$ of the dependent variable can be influenced by other factors.

\section{Table 6. R-Square Test Results}

$$
\text { Model Summary }{ }^{b}
$$

\begin{tabular}{|l|l|l|r|r|}
\hline Model & $\mathrm{R}$ & $\mathrm{R}$ Square & $\begin{array}{c}\text { Adjusted } \mathrm{R} \\
\text { Square }\end{array}$ & $\begin{array}{c}\text { Std. Error of } \\
\text { the Estimate }\end{array}$ \\
\hline 1 & $.679^{a}$ & .461 & .439 & .53312 \\
\hline
\end{tabular}

a. Predictors: (Constant), RT, N, EA, LC

b. Dependent Variable: EI

Source: SPSS Ouput 


\subsection{Discussion}

Based on the results of the assumption test and research regression above, it can be concluded that this research has met the classical assumption tests in the form of normality test, multicollinearity test, and heteroscedasticity test; which means that the model is suitable for use for multiple regression analysis after going through the t-test, F-test, and the hypothesis in the study which is not rejected.

Based on Table 4, the significant value on the regression coefficient of locus of control> 0.05 , which means that locus of control has a positive effect on entrepreneurial interest but it is not significant so that $\mathrm{H} 1$ is rejected, the significant value on the regression coefficient need for achievement $>0.05$, which means need for achievement has a positive effect on interest in entrepreneurship but not significant so that $\mathrm{H} 2$ is rejected, a significant value on the regression coefficient of risk tolerance $<0.05$, which means risk tolerance has a negative effect on interest in entrepreneurship but is significant so that $\mathrm{H} 3$ is not rejected / accepted, and a significant value on the positive entrepreneurial alertness coefficient $<0.05$, which means entrepreneurial alertness has a positive effect on interest in entrepreneurship so that $\mathrm{H} 4$ is not rejected / accepted.

According to research conducted by [17] entitled "Personality Traits on Entrepreneurial Intention", research on variables about entrepreneurial alertness is in accordance with research conducted which shows a positive and significant relationship with interest in entrepreneurship. Meanwhile, the locus of control variable, need for achievement and risk tolerance are different from the research that has been done.

In the research that has been done, the results of the hypothesis of locus of control have a positive relationship but do not have a significant effect. This research is the same as research conducted by [23] entitled: "The Influence of Innovativeness, Need for Achievement, Locus of Control, risk taking propensity and self confidence in the entrepreneurial intentions of students of the Faculty of Economics, University of Muhammadiyah Purwokerto", which shows that There is a positive relationship but it has no influence on interest in entrepreneurship, this is because locus of control is something that is "lacking" so it is considered as an important thing for students who are considered to increase interest in entrepreneurship.

From the research conducted, the hypothesis of need for achievement has a positive relationship but does not have a significant effect. This study is in accordance with the research conducted by [24] entitled: "Student Entrepreneurship Intention: A Comparative Study Between Indonesia, Japan and Norway", which shows that there is a positive relationship but has no influence on interest in entrepreneurship, this is because that the measure of achievement / need for achievement that is preferred to prioritize the success of working in the company than the choice to become an entrepreneur.

From the research conducted, the results of the hypothesis of risk tolerance have a negative but significant relationship. This is because the average student at the Faculty of Law at
Universitas Tarumanagara does not dare to take the risk of starting a business and prefers a safe way such as having a permanent job, namely as a lawyer, for example Hotman Paris Hutapea. Another reason is regional differences, which means that this research was conducted in different places and countries so that there are differences in culture, language and habits that make individual behavior able or not to accept tolerable risks to interest in entrepreneurship. This is indicated by respondents in the form of students aged 18-27 years in Jakarta who pay attention to the variables of risk tolerance and entrepreneurial alertness because these two variables have the most influential values on interest in entrepreneurship.

Outcome of these studies are not in line with the results of research conducted by researchers. However, the value that most influences the interest in entrepreneurship among students of the Universitas Tarumanagara Faculty of Law is Entrepreneurial Alertness. The influential variable is in accordance with previous research journals.

\section{CONCLUSIONS AND SUGGESTIONS}

\subsection{Conclusions}

Based on the outcome obtained, conclusion drawn that locus of control and need for achievement have a positive but insignificant effect on interest in entrepreneurship which is not in accordance with the research conducted by [17], but according to the research of [23] and [24]. Then, risk tolerance has a significant negative effect on interest in entrepreneurship, this is because the average student at the Faculty of Law at Universitas Tarumanagara does not dare to take risks to start a business and prefers a safe path such as having a permanent job. Also, entrepreneurial alertness, which has a significant positive relationship, is in accordance with [17]'s statement.

\subsection{Suggestions}

In this study, the independent variable, namely entrepreneurial alertness, has a positive influence with the highest level of significance on the dependent variable of this study, namely entrepreneurial interest, where entrepreneurial alertness has become a student mindset, so educators at Universitas Tarumanagara should be able to take advantage of and need to pay attention to and increase awareness. this is that more success will be determined by students in entrepreneurship. This is intended to strengthen students' interest in having an interest in entrepreneurship so that after graduation, students can be more confident and can realize their interest in entrepreneurship.

In subsequent studies, it can expand the object and scope of research by increasing the number of independent variables entrepreneurial characteristics in research related to student interest in entrepreneurship. 


\section{ACKNOWLEDGMENTS}

Many thanks to all respondents who have provided input, fellow researchers, Universitas Tarumanagara research institutes, and the library of the Faculty of Economics and Business, Untar.

\section{REFERENCES}

[1] Andrea Gabor dan Joseph T. Mahoney. (2010). Chester Barnard and the Systems Approach to Nurturing Organizations. Retrieved from http://www.business.illinois.edu/Working_Papers/ papers/10-0102.pdf

[2] Andrinof A. Chaniago. (2014). Pedoman penyusunan rencana pembangunan jangka menengah nasional (RPJMN), 2015-2019. Retrieved from https://www.socialprotection.org/gimi/gess/Ressource PDF.action?ressource.ressourceId=50077

[3] Kompas Cyber Media. (2017, February 11). Pemerintah Terus Motivasi Pemuda untuk Jadi Wirausahawan - Kompas.com. Retrieved from https:// ekonomi.kompas.com/read/2017/02/11/182714126/pe merintah.terus.motivasi.pemuda.untuk.jadi.wirausaha wan

[4] Pruett, M. (2012). Entrepreneurship Education: Workshops and Entrepreneurial Intentions. Journal Of Education for Business, 87(2), 94-101. DOI: 10.1080/ 08832323.2011.573594

[5] Ajzen, I. (1991). Theory of planned behavior. Organizational Behavior \& Human Decision Processes, 50, 179-211.

[6] Rotter, J.B. (1966). Generalized expectancies for internal versus external control of reinforcement. Psychological Monographs: General and Applied, 80, 1-28.

[7] Leone, C., \& Burns, J. (2000). The Measurement of Locus of Control: Assessing More Than Meets the Eye? The Journal of Psychology, 134(1), 63-76. DOI: 10. 1080/00223980009600849

[8] McClelland, D.C. (1961), The achieving society. Princeton: Van Nostrand.

[9] McClelland, D. C. (1987). Characteristics of Successful Entrepreneurs*. The Journal of Creative Behavior, 21(3), 219-233. DOI:10.1002/j.2162-6057. 1987.tb00479.x
[10] Grable J.E, (2008). Risk tolerance, in Xiao, J. J., (ed.): Handbook of Consumer Finance Research New York, Springer.

[11] March, J. G., \& Shapira, Z. (1987). Managerial Perspectives on Risk and Risk Taking. Management Science, 33(11), 1404-1418. DOI: 10.1287/mnsc.33.11. 1404

[12] Kaish, S., \& Gilad, B. (1991). Characteristics of opportunities search of entrepreneurs versus executives: Sources, interests, general alertness. Journal of Business Venturing, 6(1), 45-61. DOI: 10.1016/08839026(91)90005-x

[13] Krueger, N. F., \& Carsrud, A. L. (1993). Entrepreneurial intentions: Applying the theory of planned behavior. Entrepreneurship and Regional Development, 5(4), 315-330. http://dx.doi.org/10.1080 /08985629300000020

[14] Fini, R., Grimaldi, R., Marzocchi, G.L. and Sobrero, M. (2009), The Foundation of Entrepreneurial Intention, conference proceedings in Summer Conference 2009, June 17-19, 2009, Frederiksberg, Denmark.

[15] Bernard, H. R. (2002). Research methods in anthropology: Qualitative and quantitative approaches (3rd ed.). Walnut Creek, CA: Altamira Press.

[16] Lewis, J. L., \& Sheppard, S. R. (2006). Culture and communication: Can landscape visualization improve forest management consultation with indigenous communities? Landscape and Urban Planning, 77(3), 291-313. DOI: 10.1016/j.landurbplan.2005.04.004

[17] Karabulut, Ahu Tuğba, (2016). Personality Traits on Entrepreneurial Intention. Procedia -Social and Behavioral Sciences, 229, 12-21. DOI: 10.1016/ j.sbspro.2016.07.109

[18] Liñán, F., Rodríguez-Cohard, J. C., \& RuedaCantuche, J. M. (2011). Factors affecting entrepreneurial intention levels: a role for education. International Entrepreneurship and Management Journal, 7(2), 195-218.

[19] Sugiyono. (2014). Metode Penelitian Pendidikan Pendekatan Kuantitatif, Kualitatif, dan R\&D. Bandung: Alfabeta.

[20] Aritonang, Lerbin. R. (2007). Riset Pemasaran: Teori dan Praktik. Bogor: Ghalia Indonesia. 
[21] Malhotra, N.K. (2004). Marketing Research. An applied Orientation. $4^{\text {th }}$ Edition. Upper Saddle River, New Jersey: Pearson Education, Inc.

[22] Ghozali, Imam. (2006). Aplikasi Analisis Multivariate dengan Program SPSS (Edisi Ke 4). Semarang: Badan Penerbit Universitas Diponegoro.

[23] Endratno, H., \& Widhiandono, H. (2017). Pengaruh Innovativeness, Kebutuhan akan Prestasi, Locus of Control, risk taking propensity dan self confidence terhadap intensi kewirausahaan mahasiswa Fakultas Ekonomi Universitas Muhammadiyah Purwokerto.

[24] Indarti, N. dan Rostiani, N. (2008). Intensi Kewirausahaan Mahasiswa: Studi Perbandingan Antara Indonesia, Jepang dan Norwegia. Jurnal Ekonomika dan Bisnis Indonesia, Vol. 23, No. 4, Oktober. 